\title{
Institute of corporate responsibility in the system of valuation for stakeholders
}

\author{
Sergey Kivalov ${ }^{l}$, and Olha Kibik ${ }^{2, *}$ \\ ${ }^{l}$ National University “Odessa Law Academy”, Ukraine \\ ${ }^{2}$ National University “Odessa Law Academy”, Department of National Economy, Ukraine
}

\begin{abstract}
The principles and terms for providing corporate responsibility of economic agents of different levels are determined. Formation features of modern system for providing corporate responsibility of economic agents are examined on the example of agents operating in the field of port activity. The purpose of the article is to study concepts of development of the mechanism for corporate responsibility in order to optimize the system of stakeholders' interaction in the process of creating values. The method of system analysis was applied in studying concepts and preconditions for the functioning of corporate responsibility management systems. The systemic structural method helped in studying basic measures to increase the corporate responsibility level of enterprises of port activity. The goal of creating a system of corporate responsibility should be associated with the achievement of the maximum possible effect of functioning of the economic agent. Needs and contributions of stakeholders should be interlinked in order to increase corporate responsibility. The main stakeholders in the field of port activity and criteria for satisfying their needs, contribution and opportunities in the field of corporate responsibility have been identified. The proposed system of criteria for the effectiveness will improve the mechanism of corporate responsibility management.
\end{abstract}

\section{Introduction}

The institute of corporate responsibility plays an important role in the system of value creation in modern economic activity. Active use of tools to increase the level of corporate responsibility allows optimizing the level of competitiveness of the economic entity due to the identification of inefficient activities and unrealized opportunities, which in turn leads to the development of innovation and investment potential.

The institute of corporate responsibility, an important element of which corporate social responsibility (CSR) is, has been established in economically developed countries.

At the end of the year 2011, the EU Strategy for Corporate Social Responsibility was adopted for the period 2011-2014. According to the strategy, corporate social responsibility

\footnotetext{
*Corresponding author: kibik@ukr.net
} 
is the responsibility of the business for its impact on society. In the European Union, it is considered appropriate to have a law according to which large business entities in the form of annual accounts should include sections reflecting the results of implementing corporate social responsibility measures. In the absence of such initiatives, the business structure should provide an explanation. Currently, according to experts, less than $1 \%$ of companies report CSR [1].

Works of many scholars are devoted to the formation and development of corporate responsibility concepts. The most significant results are delivered in studies of A. Caroll [2], M. Porter, M. Kramer [3], M. Halme, J. Laurila [4], H. Aguinis and G. Ante [5] et al. The works of such Ukrainian scientists as A. Kotlubay [6], N. Primachov [7], V. Zhikhareva [6], L. Nikolaieva, V. Bereza [8] and others are devoted to the study of the process of the management system formation in maritime transport aimed at improving the potential for development of the maritime complex enterprises. Scientists from other countries, namely M. Acciaro [9], P. Alderton [10], Costas Th. Grammenos [11], P. Kieran [12], S. Kumar, J. Hoffman [13], M. Stopford [14] also paid an attention to the development of a corporate responsibility system in maritime transport.

However, issues of the corporate responsibility development as an element of the value system for economic agents of different levels and fields of activity, in particular in the field of maritime business, remain insufficiently studied.

Purpose of the article is to study principles for the development of the corporate responsibility mechanism in order to optimize the system of interaction of stakeholders in the process of creating values. The dialectical method allowed investigating the definition of a corporate responsibility. The method of system analysis was applied in studying concepts and preconditions for the functioning of corporate responsibility management systems. The systemic structural method helped in studying basic measures to increase the corporate responsibility level of enterprises of port activity.

\section{Presentation of the core material}

In recent years, the national economic system and its components are being integrated into the world socio-economic processes which make the application of tools increase the level of economic entities responsibility more active, taking into account the basics of institutional theory. The purpose of development of the corporate responsibility system is a positive impact on the economic entity environment to ensure its success and, accordingly, long period profitability. To achieve this goal, business structures must constantly analyze business processes and adapt them to modern requirements and needs of the environment, which often leads to significant costs. That is, corporate responsibility is a part of the value system of business structures, their corporate culture, and marketing policy [15].

The basic principles of corporate responsibility are defined as follows [16]:

- institutional principle of legitimacy. Comply with the current legislation, each stakeholder has certain rights and obligations, that is, has a certain degree of power. Under the condition of irresponsible attitude to their rights and obligations, economic entities may lose their power, in particular the market one;

- organizational principle of administrative liability, which provides for the organization of responsibility for those results that relate to areas of primary and secondary interaction of economic agents with society;

- individual principle of freedom of management choice, according to which economic agents are obliged to exercise the right of choice in order to ensure responsible results.

The state can be admitted as a responsible economic agent when favorable conditions are created for the comprehensive sustainable development of the socio-economic system as a whole and for its separate elements. 
Micro level economic agents are considered responsible if the following conditions are met: compliance with requirements of international and national legislation, in particular in the field of payment of taxes, production and marketing of high-quality products, implementation of corporate programs for the development of labor potential, providing for professional development, improvement of working conditions and improvement of the system of staff incentive, implementation of charitable projects and participation in regional development projects, etc.

It is necessary to determine sources of corporate responsibility and determine their impact on the corporate responsibility level. It is expedient to maintain the point of view of [16], which allocates internal and external sources. In its turn, internal sources include main components of the corporate culture. The list of external sources includes universal factors, market forces, and a political component.

The issue of increasing the corporate responsibility level for business entities, which is an important component of logistics systems, is of particular relevance. Commercial seaports and other port enterprises occupy a special place among such entities. Most of port enterprises round the world, including commercial ports, play a significant role in the development of cities, regions and even states. Accordingly, such structures should take responsible decisions considering the public interest while ensuring transparency in the adoption of such decisions. Modern enterprises of port activity operate in conditions of rapid increase of competition intensity in the national and international markets of port operations and services. Port authorities are responsible for the effective state property management in seaports and for ensuring the stable and safe business operation. Port authorities are under considerable regulatory pressure [9]. Therefore, external sources of corporate responsibility are of special importance for port enterprises. Their list should include trends in the development of the global transport market and its segments, the situation of resource markets, international and national political and legal conditions, and codes of professional associations, etc.

Leading foreign maritime business structures actively use benefits attributable to the existence of corporate responsibility systems. The results of a study by foreign scientists on the practice of implementing a corporate responsibility policy suggest that 10 well-known and successful foreign port operators have effective corporate responsibility systems. Ports of Antwerp, Hamburg, Hong Kong, Jebel Ali, Rotterdam, New York, Los Angeles, Pusan, Shanghai and Singapore actively apply initiatives such as cooperation with foreign ports, the presence of a corporate responsibility mission, environmental problems solution, educational activities, employment problem solution, gender issues, energy saving, humanitarian aid and charitable organizations support, cooperation with local communities, availability of reports on sustainable development, transparency, etc. Implementation of such initiatives results in minimizing risks of functioning and maximizing the value of port enterprises [9].

Numerous enterprises of the maritime business of Ukraine, in particular in the field of port activity, currently form and implement a system of crisis response measures, among which the improvement of the structure and methods of corporate governance is mandatory. A modern port activity feature is the large number of its participants. The main stakeholders involved in the port activity are the owners and investors of port enterprises, cargo owners, ship-owners, various intermediaries, enterprises of other modes of transport, state bodies of various levels, participants of port communities, personnel of enterprises, suppliers of various types of resources, population of territories linked to the enterprises concerned, etc. Proceeding from the stakeholders diversity, the criteria for determining the level and peculiarities of their impact on the formation of the corporate responsibility level of port enterprises differ significantly. 
Solution of the task aimed at improving the interaction between the numerous participants of port activities in the shortest possible time and at optimal cost is possible provided that the clustering processes are activated. The development of a mechanism for providing corporate responsibility allows optimizing the system of interaction of stakeholders. Moreover, the concept of stakeholders is considered an alternative of the corporate responsibility concept. Modern business structures, in particular port enterprises, are distinguished by the presence of numerous stakeholders. The main stakeholders involved in the port activity are as follows: state authorities of different levels, port authorities (port administrations), owners and investors of port enterprises, cargo owners, ship-owners, various intermediaries, enterprises of other modes of transport, participants of port communities, employees of enterprises, suppliers of various kinds of resources, etc. Based on a vast variety of stakeholders, the criteria for meeting their needs and requirements for ensuring corporate responsibility differ significantly.

The most important measures of corporate responsibility development projects for national port enterprises are considered as follows: initiatives to increase the level of resource utilization efficiency and improvement of interaction with stakeholders possessing their own economic interests. Therefore, it is necessary to consider the level of satisfaction of the stakeholders' needs, which ultimately determines the corporate responsibility level of the port enterprise. The criteria for satisfying needs of owners and investors may be the additional cost, income, profit, return on capital, other actual financial and economic indicators compared with the forecast. The criterion for customer satisfaction can be the ratio of quality of the performed port operations (services received) and the price paid. Public authorities of different levels should solve state issues, therefore criteria for them are the level of competitiveness of the port activity and the rate of impact on competitiveness of the state economy. Recently, port communities have been incorporating and developing rapidly, with the aim of increasing the competitiveness of individual actors and communities in general. Accordingly, the criteria are the level of competitiveness and profitability. Satisfaction of employees is related to the port enterprise activity in general. All employees of the enterprise of the port activity, first and foremost, are interested in the level of remuneration. Most employees strive for an interesting, creative work that allows creating and developing useful knowledge and skills. Therefore, the criteria may be tendencies of staff turnover, reasons for dismissal, level of dissatisfaction, etc. Suppliers are interested in increasing supply volumes, which is determined by the volume of port production. The criteria are the length of cooperation with the enterprise of the port activity and the volume of its purchases [17].

On the other hand, the state and other economic agents directly or indirectly involved in port activities should also adopt and implement responsible decisions in the field of cooperation with port enterprises. Especially in times of crisis, the state should take economically and politically responsible steps to support the development of the competitive potential of national port enterprises. First, the state should create a favorable regulatory environment for the functioning of port business structures in the national market and legal prerequisites for the protection of interests of domestic economic agents in the segments of the global transport market.

The contribution of stakeholders should not be ignored. The contribution means what the stakeholders can give to the enterprise of port activity in the field of providing corporate responsibility on a mutually beneficial basis. Owners and investors may contribute funds spent on the development of the port enterprise operations, in particular, business reputation, relationships with various elements of the external environment, including the clientele, state bodies, etc. The criteria for customers' input can be their loyalty to the port enterprise, the degree of readiness to confirm the positive business reputation of the enterprise, the level of customers' offers regarding the development of the enterprise, the 
level of promptitude in payment, etc.

The state contribution may be determined by the following criteria: the degree of intervention in the port enterprises activities, flexibility of the state policy in relation to the development of the port activity, the level of responsiveness to inquiries and the resolution of problem situations arising in the field of port activity, etc.

The contribution of port community participants is to support and implement a single development strategy aimed cat enhancing the entire community competitiveness. The criterion may be rough estimation of the contribution of the community in monetary terms.

The criteria for employees' contributions are the added value created by each employee, productivity, the number of proposals for improving port production, etc.

Offering attractive prices and fulfilling terms of delivery, suppliers of different types of resources create the basis for generating the desired level of responsibility of the port enterprise. The criterion for their contribution is the number of complaints regarding the quality of supply and provision of invoices.

Criteria for the effectiveness of implementing strategies aimed at raising corporate responsibility can be the number of customers, the volume and consistency of their cargo flows, trends in the volume of demand for port enterprise products, market share, attractiveness for investors, the level of satisfaction of employees of the enterprise, the contribution to improving the level of state economy competitiveness, etc.

The study of works of scientists [9] and the results of their own research activity [18] allow us to make the following conclusion. Implementation of projects to strengthen the responsibility of business structures of port activities will help to improve their competitiveness and optimize financial results through identifying inefficient areas of activity, business processes, structural units, services; identifying business opportunities that might otherwise have remained unknown; better management of stakeholders' behavior, at least the core ones; increase of innovative potential, which allows optimizing the technical and technological level of port production; solution of problems of the personnel potential development, etc.

On the other hand, other participants in the port activity will receive positive results.

Sustainable development of modern society is possible subject to the economic and political stability and increased responsibility of all economic actors, especially business structures. The external and internal environment of the modern business structure expects its responsible behavior in the field of social and economic activity. Therefore, the formation and continuous development of the corporate responsibility concept is the key to the formation of competitive advantages of modern economic agents.

\section{Conclusion}

There is a system of factors determining the development of the institute of corporate responsibility in various spheres of economic activity of society. So, the main factors of increasing the level of corporate responsibility for the sphere of port activity are strengthening of requirements for security, in particular environmental, strengthening the role of port business in the development of economic systems of different levels, development of port enterprises as logistics centers, deregulation of port activity and strengthening the intensity of competition, etc.

Every entity in the maritime business, in particular, port enterprises, must implement CR projects. Initiatives to increase corporate responsibility are prerequisites for the creation of long-term competitive advantages of the business structure of the port business in the current conditions of the world, regional and national markets development of port operations and services granted. 
The purpose of formation of the corporate responsibility system should be associated with the achievement of the maximum possible effect on the part of the economic agent, in particular ${ }_{2}$ the port enterprise. Needs and contributions of stakeholders should be interlinked in order to increase corporate responsibility, and there may be many in practice. The main stakeholders in the field of port activities can be defined as follows: owners and investors of enterprises, cargo owners, ship owners, various intermediaries, enterprises of other modes of transport, state authorities of different levels, members of port communities, employees of enterprises, suppliers of various types of resources and etc. Based on the diversity of stakeholders, the criteria for meeting their needs, contributions and opportunities in the area of corporate responsibility differ significantly. The proposed system of performance criteria to ensure corporate responsibility, considering interests of various participants in port activities, will improve the mechanism of corporate responsibility management based on the timely identification and consideration of factors for the external and internal environment of the enterprise of port activities.

\section{References}

1. New Strategy of the European Commission on Corporate Social Responsibility (CSR) 2011-2014: faster, higher, stronger. Expert Commentary from the Center for CSR Development, CSR Ukraine http://www.csr-ukraine.org (2013) Accessed 30 May 2019

2. A. Caroll, Business and Society, 38 (3), 268-295 (1999)

3. M. Porter, M. Kramer, Harvard Business Review, 84 (12), 78-92 (2006)

4. M. Halme, J. Laurila, Journal of Business Ethics, 84 (3), 325-339 (2009)

5. H. Aguinis, G. Ante, Journal of Management, 38 (4), 932-968 (2012)

6. V. Zhyhareva, A. Kotlubay, O. Kibik, Economics of Maritime Transport, Burun Knyga (2012) [in Ukrainian]

7. N. Prymachov, A. Dmytriyenko, The bulletin of transport and industry economics, 43, 57-61 (2013) [in Ukrainian].

8. L. Nikolaieva, V. Bereza, Development of administration and economic management methods on transport: Scientific works, 28, 5-13 (2013) [in Ukrainian].

9. M. Acciaro, International Journal of Logistics: Research and Applications, 18 (3), 291$311(2015)$

10. P. Alderton, Sea Transport: Operation and Economics, Tomas Reed (1998)

11. C. Th. Grammenos, Handbook of Maritime Economics and Business, LLP (2002)

12. P. Kieran, World trends in Shipping and Port reforms, CPCS, Transcom (2003)

13. S. Kumar, J. Hoffman, Globalization: The Maritime Nexus, MPG Books Ltd (2002)

14. M. Stopford, Maritime economics, Harper Collins Academic (1988)

15. S. Kivalov, O. Kibik, Baltic Journal of Economic Studies, 5 (2), 73-79 (2019)

16. L. Petrashko, Comparative Evaluation of Corporate Social Responsibility BusinessPractices: EU and Ukraine (2015-2016): the Research, KNEU (2013)

17. O.M. Kibik, The theory and methodology of pricing in sea trading ports, ONMU (2005)

18. O. Kibik, I. Khaiminova, V. Kotlubay, I. Redina, E. Belous, International Journal of Engineering \& Technology, 7 (4.3), 461-466 (2018) 